\title{
Development of Horticultural Supply Chain with Value Co-Creation to Improve Farmers' Competitiveness and Incomes
}

\author{
Muhammad Azka, Arfina Samangi, Muhammad Naufal F., and Tomy Perdana
}

\begin{abstract}
Vegetables are one of the horticultural commodities that have high economic value and opportunity in the market. However, vegetables supply chain in Indonesia is often identified with the traditional supply chain of long marketing chains, difficult market access for farmers, low competitiveness, farmers' low income, and injustice to supply chain actors, especially between farmers and wholesalers. In creating a structured supply chain, value co-creation intervention applied to synergize farmers and wholesalers in Ciwidey Sub-district to understand each other's problems then seek solutions to solve them. This research has been conducted in Ciwidey Sub-district, West Java. This research aims to measure the competitiveness and farmers income of each wholesaler's group before and after value co-creation intervention. The result shows that variables competitiveness and income of Sari Hejo Farmer Group and Hidayah Alam Farmer Group have significant positive changed, while one of three indicator variable of competitiveness has not significantly changed.
\end{abstract}

Keywords - Competitiveness, Farmer, Horticultural Supply Chain, Income, Value Co-Creation

\section{INTRODUCTION}

$\mathbf{V}$ EGETABLES as a commodity is one of the horticultural agribusiness product that is categorized as a high-value product for producers and consumers, hence have high market opportunities [9]. Its market opportunity increases along with increasing knowledge of the benefits of vegetables, increasing population and increasing people's income, concerning domestic demand and consumption of horticultural products, especially vegetables commodities tend to increase from year to year [1].

However, horticultural agribusiness also encountered several problems such as; perishable product, fluctuate price, and long marketing chains. The main problem of horticultural agribusiness is the non-optimal supply chain. The problems in the horticultural supply chain include two aspects, namely the quality of yields and market conditions [6]. Regarding yield quality, the low quality can be implicitly concluded from data that stated there are only $15 \%$ of horticultural products in Indonesia can be sold to structured markets [7]. Meanwhile, the low quality of the product is not only a problem for structured market players but also a problem for wholesalers as they often face difficulty in qualifying high-quality products from structured market participants.

At the same time, from the market perspective on marketing channels or horticulture supply chain from upstream to downstream that usually through many actors, farmers often face unfixed price [11]. Besides, the wholesalers have a decisive power with lack of transparency, and there is an unfair system of risk sharing with farmers.
Most farmers in Indonesia are controlled by the wholesalers [8]. This is because the wholesalers have a traditional position with indecisive power in their area and have the money that can be used to control farmers through credit process (in cash or production inputs, such as seeds, fertilizers, or pesticides).

In order to overcome obstacles in horticulture supply chain in Indonesia, especially traditional supply chain, transformation is needed to the structured supply chain, those are quality and quantity of high and continuous production, advanced technology investment, proper management, then have stable market price, high competitiveness, minimize risks, and inclusion of supply chain actors, especially farmers which make farmers' profits higher [4, 11]. The transformation is supported by the process of value cocreation (VCC), a form of collaborative creativity initiated by its co-creator to develop innovation and mutual value creation based on an agreement [12].

Implementing a structured supply chain with a value cocreation process, in April-June 2017 there were workshop series of value co-creation intervention created with groups of farmers and wholesalers that were part of a collaborative research between [6] Engineering Section, Faculty Technology Policy and Management TU-Delft and Agricultural Research and Supply Chain Group (Agrilogics) Universitas Padjadjaran. This research proposes an approach that recognizes the autonomy of all actors in the chain (farmers and wholesalers). In this new approach, actors are encouraged to express their problems and needs, understand each other, find solutions, and engage in decision-making to solve their challenges, or can be called empowerment of the actors. This study emphasizes that trust and commitment among actors need to be developed first, which can be done in a two-way discussion between facilitators and actors (farmers and wholesalers) on the problems and needs of farmers and wholesalers [6].

After the workshop series of value co-creation intervention, it is necessary to monitor the implementation of value cocreation intervention. Some results of value co-creation are creating a work plan to supply vegetables for Rp. 5,000/pack to the supermarkets and regular program, maintaining a continuous supply with coordination of planting schedule, communicating regularly, maintaining commitments between both actors, and creating groups farmer.

The objective of this paper is to analyze the competitiveness and income of horticultural farmers before and after value co-creation intervention. This research aims to prove that the implementation of value co-creation could develop farmers' competitiveness and income, also the horticultural supply chain.

\footnotetext{
${ }^{1}$ Agribusiness Study Program, Universitas Padjadjaran
} 


\section{Methodology}

This research had been held on April-May 2018 in Tonjong Village and Cilember Village, Ciwidey Sub-district, Bandung Regency West Java. The population is 70 people divided into two groups. The sampling technique is using simple random sampling and Slovin's formula [14] with e (error tolerance) $=$ $10 \%$. The samples are 41 people; divided as 23 people for Sari Hejo Farmer Group (Wholesaler A) and 18 people for Hidayah Alam Farmer Group (Wholesaler B).

Slovin's formula:

$$
n=\frac{N}{1+N(e)^{2}}
$$

Information:

$\mathrm{n}=$ Number of samples

$\mathrm{N}=$ Total population

$\mathrm{e}=$ Error tolerance $10 \%=0.1(1)$

Field observations were conducted to collect the data and information by using questionnaires and respondent interviews. Respondents are wholesalers and farmers in Ciwidey that join the farmer groups.

After the workshop series of value co-creation intervention, there were two established farmer groups: Sari Hejo Farmer Group and Hidayah Alam Farmer Group. These two groups also have new access to sell their agriculture product to some supermarkets.

\section{A. Value Co-Creation (VCC)}

The definition of value co-creation in the context of farmer and wholesaler who follow the concept of supply chain management is the creation of a typical value based on the agreement by its co-creator who are farmer and wholesaler [4, $6]$. The process of value co-creation is applied in the relationship between dyadic or business to business (B2B) of two companies or business partners and involves agricultural stakeholders such as the government to provide access to assistance such as counseling and other assistance programs to support the sustainability of the business. Farmers and wholesalers collaborate, work together, and interact in creating value co-creation, which becomes a part of the value co-creation process.

\section{B. Wilcoxon Test}

The analytical tool used in this research is paired with the Wilcoxon test. In the matched-sample situation, each experimental unit generates two paired or matched observations, one from population 1 and one from population 2. The differences between the matched observations provide insight into the differences between the two populations. The value of $\alpha$ used in this study is 0.05 or $5 \% . \mathrm{H}_{\mathrm{o}}$ is rejected if the probability value is less than $\alpha$ and otherwise $H_{0}$ is accepted if the probability value is higher than $\alpha$.

The other requirement is the minimum number of sample (n) for the analysis of the Wilcoxon test paired with the normal distribution is 10 sample [16]. The following hypotheses will be tested:

$\mathrm{H}_{\mathrm{o}}$ : There is no significant difference after Value CoCreation in the tested population

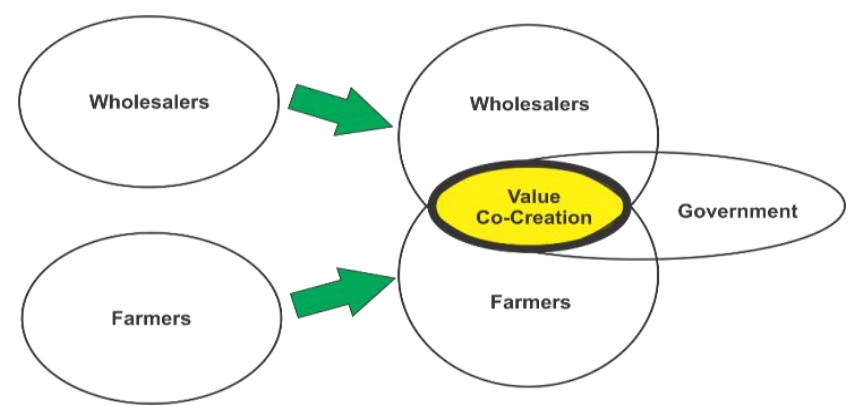

Fig. 1. The Framework of Value Co-Creation between Famers and Wholesalers [6, 13]

$\mathrm{H}_{1}$ : There is a significant difference after Value CoCreation in the tested population

\section{Competitiveness}

Competitiveness can be defined as the ability of a business to be superior to certain things [2], such as:

1. Technology used

2. Market demand

3. Value of raw material access

\section{Income}

Net income is a farmers' total earnings (or profit) and is calculated by taking revenues and subtracting the costs of doing business such as depreciation, interest, taxes and other expenses. This number appears on a farmer's income statement and is an essential measure of how profitable the farmer is over a period [5].

Net Income $=$ Total Revenues - Total Expenses

\section{RESULTS AND DISCUSSION}

The process of value co-creation consist of the first serial workshop that held in April-June 2017, helped the farmers and wholesalers to establish farmer groups during SeptemberNovember 2017, helped the farmer's group to have new access to the supermarkets during September-November 2017, and held the second workshop in April 2018 for evaluation. Farmers and wholesalers united into one farmer group entity, the local government only facilitate it.

The result of the first workshop is to recognize common challenges and its solutions. Establishing farmer groups and having new access to the supermarkets are two challenges that had been done. The second workshop was held to evaluate the progress of value co-creation and to recognize the new challenges.

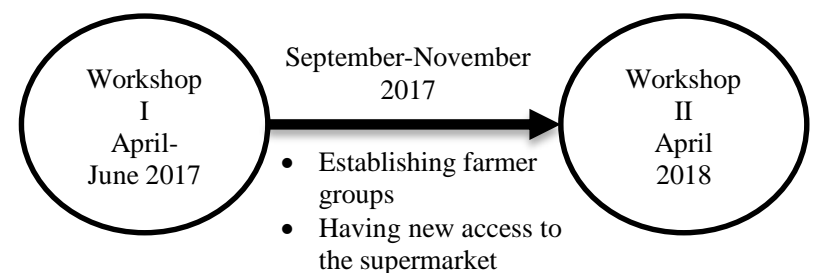

Fig. 2. The Process of Value Co-Creation in Ciwidey Sub-district 
From the social aspect, collaboration and coordination between farmers and wholesaler are getting better since last year. The following are result and discussion of how significant changes the farmers' competitiveness and net income change after value co-creation intervention:

\section{A. Competitiveness}

1) Sari Hejo Farmer Group: Compared with the situation before the VCC intervention, the indicator variable technology used has significantly changed positively because there are new packing tools to supply vegetables to supermarkets in Bandung and Wholesaler A lent to his farmers the machine pesticide sprayers (previously manual). The market has significantly changed positively because Sari Hejo Farmer Group collaboration with Locarvest to supply vegetables to supermarkets in Bandung; also Alamanda demand for watercress has increased. The value of raw material access has not any significant change because, before the VCC, agricultural input shops are near and complete; also the stock of production input goods always be supplied.

2) Hidayah Alam Farmer Group: Compared with before the VCC intervention, the indicator variable technology used has not significantly changed because of technology used by farmers the same as before VCC intervention, traditional technology such as hie, machete, manual pesticide sprayer, and others. Even though Wholesaler B has packing tools (machine) to supply vegetables to supermarkets in Bandung, but the farmers do not satisfied with the tools because they have no impact on their planting process. The market has significantly changed positively because Hidayah Alam Farmer Group collaboration with Locarvest to supply vegetables to supermarkets in Bandung; also traditional market demand for vegetables has increased. The value of raw material access does not have any significant changes because, before the VCC, agricultural input shops are near and complete; also the stock of production input goods is always be supplied.

\section{B. Income}

Farmers and wholesalers got new access to supermarkets in December 2017. Every product that sells to supermarkets gets post-harvest treatments: sorting and packaging. The products are also labeled as fresh and economical vegetables, called Locarvest. A study in customer value mapping analysis (for tomatoes) shows that branding and packaging might bring superior competitive advantage on the tomatoes produce marketing [15].

1) Sari Hejo Farmer Group: Compared with the situation before VCC intervention, the income has significantly increased because market demand has increased such as PT. Alamanda Sejati Utama for export watercress to Singapore, Locarvest to supply horticulture commodities to supermarkets in Bandung, and watercress sales price has increased from Rp. $1,025 / \mathrm{kg}$ in 2017 to Rp. $1,275 / \mathrm{kg}$ in 2018. The average of increasing income is $48.23 \%$. Two celery farmers' income has decreased because the celery commodity was not for sale in export or
TABLE I. RECAPITULATION OF WILCOXON NON-PARAMETRIC STATISTICAL TEST RESULT IN PAIRS FOR COMPETITIVENESS VARIABLES OF SARI HEJO FARMER GROUP

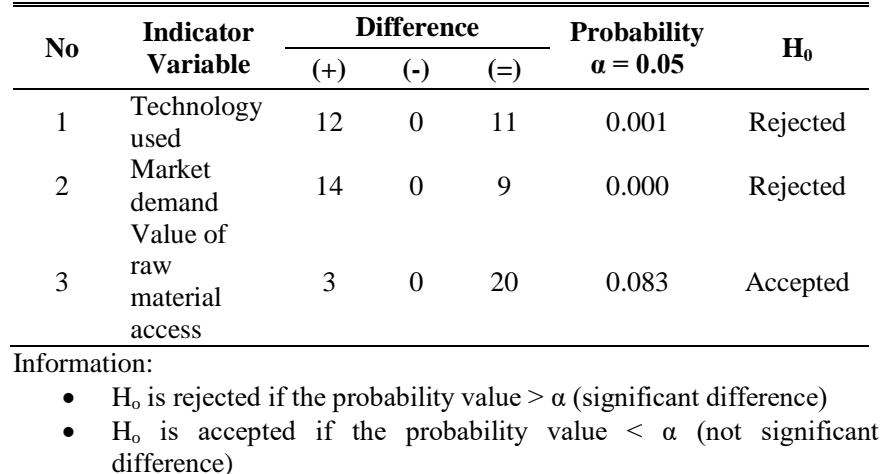

TABLE II. RECAPITULATION OF WILCOXON NON-PARAMETRIC STATISTICAL TEST RESULT IN PAIRS FOR COMPETITIVENESS VARIABLES OF HIDAYAH ALAM FARMER GROUP

\begin{tabular}{|c|c|c|c|c|c|c|}
\hline \multirow{2}{*}{ No } & \multirow{2}{*}{$\begin{array}{l}\text { Indicator } \\
\text { Variable }\end{array}$} & \multicolumn{3}{|c|}{ Differences } & \multirow{2}{*}{$\begin{array}{c}\text { Probability } \\
\alpha=0.05\end{array}$} & \multirow{2}{*}{$\mathbf{H}_{0}$} \\
\hline & & $(+)$ & $(-)$ & $(=)$ & & \\
\hline 1 & $\begin{array}{l}\text { Technology } \\
\text { used }\end{array}$ & 4 & 0 & 14 & 0.059 & Accepted \\
\hline 2 & Market demand & 11 & 0 & 7 & 0.001 & Rejected \\
\hline 3 & $\begin{array}{l}\text { Value of raw } \\
\text { material access }\end{array}$ & 1 & 0 & 17 & 0.317 & Accepted \\
\hline
\end{tabular}

Information:

- $\mathrm{H}_{\mathrm{o}}$ is rejected if the probability value $>\alpha$ (significant difference)

- $\mathrm{H}_{\mathrm{o}}$ is accepted if the probability value $<\alpha$ (not significant difference)

TABLE III. RECAPITULATION OF WILCOXON NON-PARAMETRIC STATISTICAL TEST RESULT IN PAIRS FOR INCOME VARIABLE OF SARI HEJO FARMER GROUP

\begin{tabular}{cccccccc}
\hline \hline \multirow{2}{*}{ No } & \multirow{2}{*}{$\begin{array}{l}\text { Indicator } \\
\text { Variable }\end{array}$} & \multicolumn{3}{c}{ Differences } & Probability & $\mathbf{H}_{\mathbf{0}}$ \\
\cline { 3 - 5 } & $(+)$ & $(-)$ & $(=)$ & $\boldsymbol{\alpha}=\mathbf{0 . 0 5}$ & \\
\hline 1 & Income & 21 & 2 & 0 & 0.000 & Rejected \\
\hline
\end{tabular}

Information:

- $\mathrm{H}_{\mathrm{o}}$ is rejected if the probability value $>\alpha$ (significant difference)

- $\mathrm{H}_{\mathrm{o}}$ is accepted if the probability value $<\alpha$ (not significant difference)

TABLE IV. RECAPITULATION OF WILCOXON NON-PARAMETRIC STATISTICAL TEST RESULT IN PAIRS FOR INCOME VARIABLE OF HIDAYAH ALAM FARMER GROUP

\begin{tabular}{|c|c|c|c|c|c|c|}
\hline \multirow{2}{*}{ No } & \multirow{2}{*}{$\begin{array}{l}\text { Indicator } \\
\text { Variable }\end{array}$} & \multicolumn{3}{|c|}{ Differences } & \multirow{2}{*}{$\begin{array}{c}\text { Probability } \\
\alpha=0.05\end{array}$} & \multirow{2}{*}{$\mathbf{H}_{\mathbf{0}}$} \\
\hline & & $(+)$ & $(-)$ & $(=)$ & & \\
\hline 1 & Income & 15 & 3 & 0 & 0.048 & Rejected \\
\hline
\end{tabular}

- $\mathrm{H}_{\mathrm{o}}$ is accepted if the probability value $<\alpha$ (not significant difference)

supermarket in Bandung, but only for sale in the traditional market until March 2018. Before March 2018, the celery's price depends on market price (fluctuating), not with contract price (fixed). In the average selling price of celery commodity, still, the previous price for the year 2017 is higher than 2018 . Besides, total expenses for planting also increased since last year.

2) Hidayah Alam Farmer Group: Compared with the situation before VCC intervention, the income has significantly increased because market demand has 
increased such as Locarvest for horticulture commodities supply to supermarkets in Bandung and traditional markets in Bandung and Jakarta. The average of increasing income is $16.30 \%$. Three farmers' income with tomato, chili pepper, and chicory commodities had decreased. Tomato farmer got same average price, but total expenses for planting has increased since last year. Meanwhile, chili pepper and chichory farmers got lower price than previous year because the demand from supermarkets was still low and the price followed traditional market price, which could be changed significantly in one day (fluctuation), also harvesting time affects product price according to market conditions. Besides, total expenses for planting also increased since last year.

Most of the commodities selling price of farmers has increased since last year. Prices do not only increase but are relatively stable, fixed, and transparent due to the presence of Rp. 5,000/pack program contract in the supermarkets. Of the 10 commodities planted since last year, 9 commodities experienced price increases and only 1 commodity experienced a price decline, which is celery commodity. The price of celery goes down because the celery was not supplied to the supermarket but only supplied to traditional market until March 2018. At the end of March 2018, celery was supplied to supermarkets, but the number of demand was still small. Last year the price of celery was higher because the demand of the traditional market for celery, especially before holidays was high, so the average of the price for last year was higher. If the demand for celery from supermarkets continues to increase throughout 2018 at a relatively stable price, the average profit from the sale of celery could increase. So, value co-creation could be applied without differentiating commodities.

Before supplying regularly to supermarkets, the wholesaler receives farmers' harvest without ordering (except watercress to Alamanda) because if the wholesaler makes an order, the wholesaler cannot ascertain the price of the commodity when the harvest time arrives. However, after supplying regularly to supermarkets, the wholesaler has started ordering on several commodities that have been continuously sent vegetables with high demand.

\section{CONCLUSION}

The technology used indicator variable in the competitiveness variable has a significant positive change after the VCC intervention on Sari Hejo Farmer Group, while the Hidayah Alam Farmer Group has not found significant differences. The sign of the market demand of the two groups has a significant positive change. The value of raw material access of the two groups has not significantly developed. The income of two groups after the VCC intervention have significantly improved.

VCC is suitable to be implemented in the horticulture supply chain because it involves various stakeholders to create value/ agreement, those are farmers and wholesalers. The increasing income proves VCC suitability, and some
TABLE V. AVERAGE SELLING PRICE OF FARMERS

\begin{tabular}{lcc}
\hline \hline \multirow{2}{*}{ Commodities } & \multicolumn{2}{c}{$\begin{array}{c}\text { Average Selling } \\
\text { Price (Rp/kg) }\end{array}$} \\
\cline { 2 - 3 } & $\mathbf{2 0 1 7}$ & $\mathbf{2 0 1 8}$ \\
\hline Tomato & $3,150.0$ & $3,283.3$ \\
Bean & $3,187.5$ & $3,387.5$ \\
Cabbage & $1,850.0$ & $2,000.0$ \\
Chicory & $1,340.0$ & $1,400.0$ \\
Chili pepper & $15,500.0$ & $16,000.0$ \\
Watercress & $1,025.0$ & $1,275.0$ \\
Nut & $4,500.0$ & $5,000.0$ \\
Celery & $6,750.0$ & $6,250.0$ \\
Cauliflower & $3,000.0$ & $3,200.0$ \\
Leek & $3,000.0$ & $3,250.0$ \\
\hline
\end{tabular}

indicator variables competitiveness has significant positive changed. It is expected that this VCC method can be implemented in other areas by involving more various stakeholders such as government and investor. This is suitable to develop horticulture sector in a country with the majority of small-scale farmers.

\section{ACKNOWLEDGMENT}

We would like to thank the farmers involved in our research as respondents and Universitas Padjadjaran for providing facility and support in this research. We also would like to thank the Ministry of Research, Technology, and Higher Education of Indonesia for funding and supporting this research to be presented in the Student Creativity Program (PKM).

\section{REFERENCES}

[1] Badan Pusat Statistik (BPS), "Konsumsi Buah dan Sayur Susenan Maret 2016: Dalam rangka Hari Gizi Nasional," 25 Januari 2017, [Online]. Available : http://gizi.depkes.go.id/wpcontent/uploads/2017/01/Paparan-BPS-Konsumsi-Buah-Dan-Sayur.pdf.

[2] S. R. Bintari and L. Sertiatiti, "Pengukuran Daya Saing Usaha Mikro Kecil dan Menengah Menyongsong Masyarakat Ekonomi ASEAN,' Jurnal Ekonomi dan Studi Pembangunan Vol. 14, No. 2, 2013, pp. 153 162.

[3] D. W. Brinkerhoff, and P. J. Morgan, "Capacité and Capacity Development Coping with Complexity, "Public Administration and Development, 2010, 30(1):2-10 DOI 10.1002/pad.559.

[4] Y. Handayati., T. M. Simatupang, and T. Perdana, "Value co-creation in Agri-chains Network: an Agent-Based Simulation," Industrial Engineering and Service Science, IESS 2015, Procedia Manufacturing 4, 2015, pp. $419-428$

[5] D. E. Kieso, J. J. Weygandt, and T. D. Warfield, "Intermediate. Accounting Fifteenth Edition," 2013, United States of America: Wiley.

[6] K. Kusnandar, "Empowering Horticultural Chain Actors in Indonesia: Case of West Java," 2017, Systems Engineering Section, Technology Policy, and Management. TU-Delft, Netherlands, UNPUBLISHED.

[7] R.S. Natawidjaja, T. Reardon, S. Shetty, T. Noor, T. Perdana, E Rasmikayati, S. Bachri, and R. Hernandez, "Horticultural producers and supermarket development in Indonesia," 2007, no. 38543.

[8] R. S. Natawidjaja, I. A. Rum, L. Sulistyowati, and Z Saidah, "Improving the participation of smallholder mango farmers in modern retail channels in Indonesia," Int. Rev. Retail. Distrib. Consum. Res., vol. 24,2014 , no. 5 , pp. $564-580$. 
[9] T. Perdana, "Manajemen Rantai Pasokan Hortikultura untuk Memenuhi Pasar Ekspor: Bajan Presentasi pada Lokakarya Manajemen Rantai Pasokan Hortikultura untuk Memenuhi Pasar Ekspor," pada 28 Desember 2009. Universitas Padjadjaran, Indonesia.

[10] T. Perdana, "The Future of Smallholders Farmers: Value co-creation as an Intervention to Empower Agricultural Chain Actors," Indonesia Development Forum 2017 in Jakarta.

[11] T. Perdana and K. Kusnandar, "The Triple Helix Model for fruits and vegetables supply chain management development involving small farmers in order to fulfill the global market demand: A case study in value chain center," Universitas Padjadjaran. Procedia-Social and Behavioral Sciences. 2012, 52: 80-89.

[12] C. K. Prahalad, "The co-creation of value," Emerald Journals database: vol. 68,2004, p. 23.

[13] C. K. Prahalad and V. Ramaswamy, "Co-Creation Experiences: The Next Practice in Value Creation," Journal Of Interactive Marketing vol. 18, number 3, 2004, p. 11.

[14] Sugiyono, "Metode Penelitian Kuantitatif dan Kualitatif," R\&D. Alfabeta, 2013, p. 96.

[15] H. N. Utami, A. H. Sadeli, and T. Perdana, "Customer Value Creation of Fresh Tomatoes through Branding and Packaging as Customer Perceived Quality," J. ISSAAS, vol. 22, 2016, pp. 123-136.

[16] T. A. Williams, D. J. Sweeney, and D. R. Anderson, "Statistics for Business and Economics," 2008, Thomson South-Western, USA. 